Potravinarstvo Slovak Journal of Food Sciences

vol. 14, 2020, p. 224-229

https://doi.org/10.5219/1309

Received: 6 February 2020. Accepted: 5 April 2020.

Available online: 28 April 2020 at www.potravinarstvo.com

(C) 2020 Potravinarstvo Slovak Journal of Food Sciences, License: CC BY 3.0

ISSN 1337-0960 (online)

\title{
MILK YIELD AND SOMATIC CELLS IN DAIRY EWES WITH RESPECT TO THEIR MUTUAL RELATIONS
}

\author{
Marta Oravcová, Kristína Tvarožková, Vladimír Tančin, Michal Uhrinčat', Lucia Mačuhová
}

\begin{abstract}
The objective of this study was to analyze milk yield and somatic cell count (SCC) expressed as somatic cell sore (SCS) in Lacaune dairy breed. Data from milk performance testing recorded between 2016 and 2018 (farm in West Slovakia) were used. A total, 377 individual milk yield and SCC records of 61 ewes (first, second and third lacation, respectively) were analysed. Mixed model for milk yield included fixed factors: SCC class (lowest, low, middle, high and highest), year of measurement, lactation number, month in milk and interaction between month in milk and SCC class, and random factors of ewe and error. Mixed model for SCS included milk yield class (lowest, low, middle, high, highest), year of measurement, lactation number, month in milk and interaction between month in milk and milk yield class. Random factors of ewe and error were considered as well. Milk yield was significantly affected $(p<0.05$ or $p<0.01)$ by all investigated factors. Except for interaction between month in milk and milk yield class, the remaining factors significantly affected $(p<0.05$ or $p<0.01)$ also SCS. The analyses confirmed that SCC may be used as a useful indicator of udder health. It may help in identifying infected ewes, and thus, avoiding mammary infections to be spread throughout the whole flock.
\end{abstract}

Keywords: Lacaune; milk yield; somatic cell count and score; SCC; Slovakia

\section{INTRODUCTION}

Dairy sheep sector is a traditional branch of livestock in Slovakia. In order to be competitive, an increase of milk yield of good quality remains one of the most important goals od sheep farms. However, this aim may be a potential risk for udder health. Consumers, on the other hand, are more iterested in welfare of animals (Tančin et al., 2019), when deciding which food to buy. Types of breeding systems and (also welfare) thus influence both ewe production abilities and health/desease conditions. Somatic cells are considered to be of a negative effect on health of mammary gland and are used for detection of udder infection in ewes (Gonzalo et al., 1994; GonzálesRodríguez et al., 1995; Tvarožková et al., 2019). The consequence of increased SCC is decreasing raw milk quality, which has further consequences for milk processing (Hag, 2001). Mastitis is a costly health problem in dairy ewes (Arias et al., 2012); mammary infections damage udder tissue (Burriel, 1997).

Tvarožková et al. (2019) summarised knowledge about defining the physiological/pathological levels of somatic cell count (SCC) and of proposing the possible tresholds for healthy mammary gland in ewes (Pengov, 2001; Berthelot et al., 2006; Sutera et al., 2018). These values vary among dairy sheep breeds and no single value to differentate between uninfected and infected udder was accepted (Berthelot et al., 2006; Tančin et al., 2017). For example, tresholds for healthy udders in ewes may be as follows: $265 \times 10^{3}$ somatic cells.mL ${ }^{-1}$ (Caboni et al., 2017), $300 \times 10^{3}$ somatic cells.mL ${ }^{-1}$ (Kern et al., 2013) or $500 \times 10^{3}$ somatic cells. $\mathrm{mL}^{-1}$ (Sutera et al., 2018). Gonzalo et al. (1994) and El-Saied, Carriedo and San Primitivo (1998) recommended SCC values ranging from $2.5 \times 10^{5}$ to $3 \times$ $10^{5}$ cells.ml ${ }^{-1}$ as thresholds between healthy and infected udders. According to Jaeggi et al. (2003), thresholds above $1000 \times 10^{3}$ somatic cells. $\mathrm{mL}^{-1}$ decrease the cheese yield and increase the development of rancid flavours in the cheese.

No routine determination of SCC in individual ewes is undertaken on national level in Slovakia; however, there are farms interested in SCC to be known due to fact that costs to cure infected individuals and the decrease of milk yield may affect the profitability. In Slovakia, reports aimed at investigation of SCC and distributions of ewes in respective SCC classes as well as their influence on milk yield and composition were published (Idriss et al., 2015; Tančin et al., 2017); possible values that enable to distinguish between ewes infected/uninfected with mastitis were discussed (Oravcová, Mačuhová and Tančin, 2018; Tvarožková et al., 2019).

In spite of fact that some analyses were done, this study was aimed at providing in-depth investigation of mutual relations between SCC and milk yield on a level of a 
single farm. Purebred Lacaune ewes were included in the analysis.

The hypothesis was as follows: SCC negatively influences amount of milk yield; vice versa amount of milk yield negatively influence SCC.

\section{MATERIAL AND METHODOLOGY}

Data were collected from the farm located in western Slovakia during the period of three years (from 2016 to 2018). Milk yield and somatic cell count (SCC) of Lacaune (LC) ewes were analysed. Test-day records were taken once per month (under the the guidance of certificated organisation for milk recording i.e. Plemenárske služby, š. p. SR Bratislava). Ewes were machine milked two times per day after lambs were weaned. However, only morning milkings were taken into account.

A total of 667 records of 61 ewes with 95 lactations i.e. 1.56 lactation per ewe) were included. Ewes were in their first, second and third lactation, respectively.

Ewes predominantly lambed in February and March. According to their lambing, ewes were on their second to sixth month in milk (MIM): MIM 2 (30 to 60 days after lambing), MIM 3 (61 to 90 days after lambing), MIM 4 (91 to 120 days after lambing), MIM 5 (121 to 150 days after lambing) and MIM 6 (151 and 180 days after lambing). Due to only six measurements taken between 181 and 194 days, these were included in MIM6. At least, ewes with three test-day records per lactation were considered.

According to SCC, five classes were formed: lowest SCC (under or equal to $200 \times 10^{3}$ cells. $\mathrm{mL}^{-1}$ ), low SCC (between $200 \times 10^{3}$ and $400 \times 10^{3}$ cells. $\mathrm{mL}^{-1}$ ) middle SCC (between $400 \times 10^{3}$ and $600 \times 10^{3}$ cells.mL $L^{-1}$ ), high SCC between $600 \times 10^{3}$ and $1000 \times 10^{3}$ cells. $\mathrm{mL}^{-1}$ ) and highest SCC (above $1000 \times 10^{3}$ cells. $\mathrm{mL}^{-1}$ ). Because of non-normal distribution of SCC, these values were transformed and somatic cell score i.e. $\mathrm{SCS}=\log _{2}(\mathrm{SCC} / 100000)+3$, as mentioned by Riggio et al. (2007), was analysed. According to milk yield (MY), five classes were also formed: lowest MY (under or equal to $200 \mathrm{ml}$ ), low MY (between 200 and $400 \mathrm{ml}$ ) middle class MY (between 400 and $600 \mathrm{ml}$ ), high MY between 600 and $1000 \mathrm{ml}$ ) and highest MY (above 1000 $\mathrm{ml})$.

The mixed model methodology using MIXED procedure (SAS 9.2, 2009) was applied to study the influence of factors affecting the variation of milk yield and SCS. Two different models were considered. The model equation (1) was used for milk yield:

$y_{i j k l m n}=\mu+Y_{i}+L_{j}+M_{k}+C_{l}+M_{k} C_{l}+u_{m}+e_{i j k l m n}$

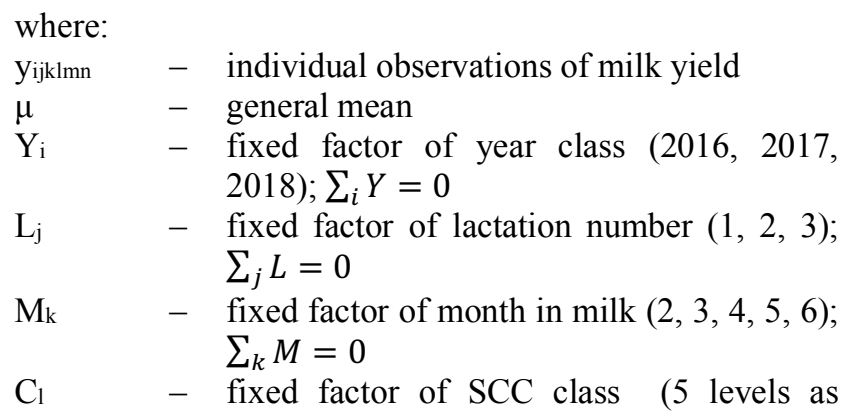

mentioned above); $\sum_{l} C=0$

$\mathrm{M}_{\mathrm{k}} \mathrm{C}_{1} \quad$ - fixed factor of interaction between month in milk and SCC class; $\sum_{k l} M C=0$

$\mathrm{u}_{\mathrm{m}} \quad-$ random factor of ewe (1, 2 to 61); $u_{m} \sim N\left(0, I \sigma_{m}^{2}\right)$

$\mathrm{e}_{\mathrm{ijk} \mathrm{jlm} n} \quad-\quad$ random error; $e_{i j k l m n}=N\left(0, I \sigma_{e}^{2}\right)$

The model equation (2) was used for SCS:

$$
y_{i j k l m n}=Y_{i}+L_{j}+M_{k}+C_{l}+M_{k} C_{l}+u_{m}+e_{i j k l m n}
$$

where:

\begin{tabular}{|c|c|}
\hline $\mathrm{y}_{\mathrm{ijk} l m n}$ & - individual SCS \\
\hline$\mu$ & - general mean \\
\hline$Y_{i}$ & $\begin{array}{l}\text { - fixed factor of year }(2016,2017,2018) \text {; } \\
\sum_{i} Y=0\end{array}$ \\
\hline $\mathrm{L}_{\mathrm{j}}$ & $\begin{array}{l}\text { - fixed factor of lactation number }(1,2,3) \text {; } \\
\sum_{j} L=0\end{array}$ \\
\hline $\mathrm{M}_{\mathrm{k}}$ & $\begin{array}{l}-\quad \text { fixed factor of month in milk }(2,3,4,5,6) \\
\sum_{j} M I M=0\end{array}$ \\
\hline $\mathrm{C}_{1}$ & $\begin{array}{l}\text { fixed factor of milk yield class ( } 5 \text { levels as } \\
\text { mentioned above); } \sum_{l} C=0\end{array}$ \\
\hline $\mathrm{M}_{\mathrm{k}} \mathrm{C}_{\mathrm{l}}$ & $\begin{array}{l}\text { - fixed factor of interaction between month in } \\
\text { milk number and milk yield class; } \\
\sum_{k l} L M I M=0\end{array}$ \\
\hline $\mathrm{u}_{\mathrm{m}}$ & $\begin{array}{l}\text { random factor of ewe }(1,2 \text { to } \\
u_{m} \sim N\left(0, I \sigma_{m}^{2}\right)\end{array}$ \\
\hline $\mathrm{ijk} \ln$ & random error; $e_{i j k l m n}=N\left(0, I \sigma_{e}^{2}\right)$ \\
\hline
\end{tabular}

Fixed factors included in the models (1) and (2) were estimated using the Least Squares Means (LSM) method. Statistical significances of fixed factors were tested by Fischer's F-test; statistical significances of individual differences between estimated levels of fixed factors were tested by Scheffe's multiple-range tests. Differences were considered statistically significant when $p<0.05$ or $p<0.01$. Ewe and residual error variances were estimated using the Restricted Maximum Likelihood (REML) method. Estimated variances enable to estimate repeatability of MY and SCS and can be interpreted as the proportion of total variance attributable to withinindividual variance:

$$
r^{2}=\frac{\sigma_{m}^{2}}{\sigma_{m}^{2}+\sigma_{e}^{2}}
$$

\section{RESULTS AND DISCUSSION}

Analysis of variance of fixed factors affecting milk yield (MY) and (SCS) of Lacaune (LC) ewes is given in Table 1. The factors of year of measurement (three years included to increase number of observations), lactation number and month in milk (MIM) were significant $(p<0.05$ or $p<0.01)$. Both, the factor of somatic cell count (SCC) class when MY as dependent variable was analysed and the factor of MY class when SCS as dependent variable was analysed, were significant $(p<0.01)$. The factor of interaction between MIM and SCC class (model 1) was significant $(p<0.01)$. The factor of interaction between MIM and MY class (model 2) was non-significant $(p>0.05)$. Differences in studied traits with respect to individual levels of factors included in models are discussed below. 
Table 1 Analyses of variance (statistical significance of Fisher F-test) for milk yield and somatic cell score.

\begin{tabular}{|c|c|c|}
\hline \multirow[b]{2}{*}{ Factor } & \multicolumn{2}{|c|}{ Traits } \\
\hline & MY & SCS \\
\hline Year & ++ & + \\
\hline Lactation number & + & + \\
\hline MIM & ++ & + \\
\hline SCC class & ++ & N.C. \\
\hline MY class & N.C. & ++ \\
\hline MIM*SCC class & + & N.C. \\
\hline MIM*MY class & N.C. & - \\
\hline
\end{tabular}

Note: MY - milk yield, SCS - somatic cell score, MIM - month in milk, SCC - somatic cell count, N.C. - not considered, ${ }^{++} p<0.01,{ }^{+} p<0.05,{ }^{-} p>0.05$.

Table 2 Least squares means and standard errors for milk yield by somatic cell count class and for somatic cell score for somatic cell score by milk yield class.

\begin{tabular}{|c|c|c|c|c|c|}
\hline \multirow[b]{5}{*}{ Trait } & \multicolumn{5}{|c|}{ SCC class $\left(10^{3}\right.$ cells.ml $\left.{ }^{-1}\right)$} \\
\hline & Lowest (1) & Low (2) & Middle (3) & High (4) & Highest (5) \\
\hline & $\leq 200$ & $>200 \leq 400$ & $>400 \leq 600$ & $>600 \leq 1000$ & $>1000$ \\
\hline & $\mathrm{n}=10$ & $\mathrm{n}=57$ & $\mathrm{n}=138$ & $\mathrm{n}=142$ & $\mathrm{n}=30$ \\
\hline & $\mu \pm s_{\mu}$ & $\mu \pm s_{\mu}$ & $\mu \pm s_{\mu}$ & $\mu \pm s_{\mu}$ & $\mu \pm s_{\mu}$ \\
\hline MY (ml) & $647 \pm 23$ & $561 \pm 27$ & $573 \pm 37$ & $487 \pm 39$ & $538 \pm 24$ \\
\hline \multirow[t]{5}{*}{ Scheffe's tests } & & & $1: 2^{+}, 3^{++}, 4^{++}$ & & \\
\hline & \multicolumn{5}{|c|}{ MY class (ml) } \\
\hline & Lowest (1) & Low (2) & Middle (3) & High (4) & Highest (5) \\
\hline & $\leq 200$ & $>200 \leq 400$ & $>400 \leq 600$ & $>600 \leq 1000$ & $>1000$ \\
\hline & $\mathrm{n}=10$ & $\mathrm{n}=57$ & $\mathrm{n}=138$ & $\mathrm{n}=142$ & $\mathrm{n}=30$ \\
\hline Trait & $\mu \pm s_{\mu}$ & $\mu \pm s_{\mu}$ & $\mu \pm s_{\mu}$ & $\mu \pm s_{\mu}$ & $\mu \pm s_{\mu}$ \\
\hline SCS & $6.69 \pm 0.83$ & $6.43 \pm 0.36$ & $5.21 \pm 0.27$ & $4.95 \pm 0.27$ & $3.97 \pm 0.47$ \\
\hline Scheffe's tests & & & $2: 3^{+}, 4^{++}, 5^{++}$ & & \\
\hline
\end{tabular}

Note: MY - milk yield, SCS - somatic cell score, $\mathrm{SCC}-$ somatic cell count, ${ }^{++} p<0.01,{ }^{+} p<0.05$.

Table 3 Least squares means and standard errors for milk yield and somatic cell score by year of measurement, lactation number and month in milk.

\begin{tabular}{lccc}
\hline Factor & & MY $(\mathbf{m l})$ & Traits \\
\hline Year & $\mathrm{n}$ & $\mu \pm s_{\mu}$ & SCS \\
$2016(1)$ & 138 & $556 \pm 28$ & $\mu \pm s_{\mu}$ \\
$2017(2)$ & 138 & $602 \pm 24$ & $5.62 \pm 0.31$ \\
$2018(3)$ & 101 & $526 \pm 28$ & $4.91 \pm 0.31$ \\
Scheffe's tests & & $2: 3^{++}$ & $5.72 \pm 0.35$ \\
\hline Lactation number & & & $2: 3^{++}$ \\
First (1) & 145 & $517 \pm 26$ & $5.90 \pm 0.33$ \\
Second (2) & 127 & $584 \pm 25$ & $4.80 \pm 0.30$ \\
Third (3) & 105 & $583 \pm 29$ & $5.64 \pm 0.35$ \\
Scheffe's tests & & $1: 2^{+}$ & $1: 2^{+}$ \\
\hline Month in milk & & $733 \pm 33$ & \\
$30-60$ days (2) & 55 & $667 \pm 27$ & $5.71 \pm 0.37$ \\
61-90 days (3) & 81 & $565 \pm 29$ & $6.19 \pm 0.33$ \\
$91-120$ days (4) & 86 & $454 \pm 28$ & $5.29 \pm 0.32$ \\
121-150 days (5) & 86 & $389 \pm 29$ & $4.99 \pm 0.33$ \\
$>151$ days (6) & 69 & $2: 4^{++}, 5^{++}, 6^{++} 3: 5^{++}, 6^{++} 4: 5^{+}, 6^{+}$ & $5.07 \pm 0.34$ \\
Scheffe's tests & & $2: 4^{+}$ \\
\hline
\end{tabular}

Note: MY - milk yield, SCS - somatic cell score, $\mathrm{n}$ - number of observations, ${ }^{++} p<0.01,{ }^{+} p<0.05$. 


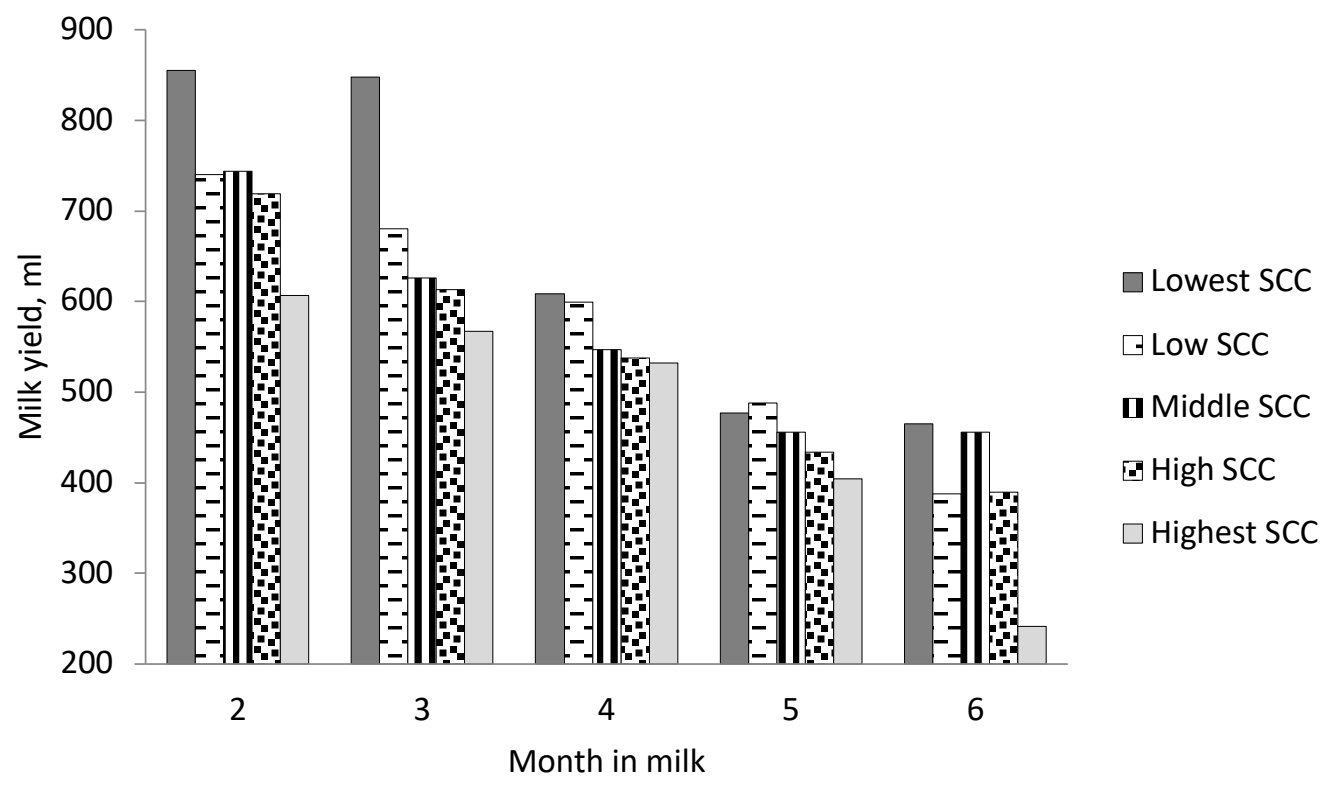

Figure 1 Milk yield in dependence of month in milk and somatic cell count class.

Least squres means (LSM) of MY and SCS confirmed negative relations between these traits (Table 2) i.e. the higher MY, the lower SCS is found. With increasing SCC (model 1), MY deacreased, with exception between classes with $\mathrm{SCC}>600 \leq 1000$ and $>1000 \times 10^{3}$ cells. $\mathrm{mL}^{-1}$. The differences between these classes, however, were found non-significant and respective LSM are probably affected by distribution of observations and their lower number (especially in highest SCC class). Accordingly, SCS increased with decreasing MY (model 2). Some differences between individual levels of MY class were also found non-signignicant. The proportion of highest SCC class of i.e. SCC above $1000 \times 10^{3}$ cells.mL ${ }^{-1}$ was $8 \%$ of milk records. The proportion of records with SCC under or equal to $200 \times 10^{3}$ cells. $\mathrm{mL}^{-1}$ (lowest class of SCC) was only $3 \%$. The most of records fell in classes with $\mathrm{SCC}>400 \times 10^{3} \leq 600 \times 10^{3}$ cells. $\mathrm{mL}^{-1}$ (middle SCC class) and $\mathrm{SCC}>600 \times 10^{3} \leq 1000 \times 10^{3}$ cells.mL $\mathrm{mL}^{-1}$ (higher SCC class) i.e. $37 \%$ per each. The remaing proportion $(15 \%)$ fell in class with SCC $>200 \times 10^{3} \leq 400 \times 10^{3}$ cells.mL $\mathrm{mL}^{-1}$ (lower SCC class). According to these findings, about $90 \%$ of ewes had healthy udders (or may be of subclinical mastitis udders) as compared with report of Gonzalo et al. (1994), who recommended SCC values ranging from $500 \times 10^{3}$ to $1000 \times 10^{3}$ cells. $\mathrm{mL}^{-1}$ as thresholds between healthy and infected udders. When comparing with reports El-Saied, Carriedo and San Primitivo (1998), Caboni et al. (2017) and Kern et al. (2013) who recommended SCC values ranging from $250 \times 10^{3}$ to $300 \times 10^{3}$ cells. $\mathrm{mL}^{-1}$ as thresholds of healthy udders, the proportion of ewes those could suffer from subclinical mastitis icreased. Regarding distribution of ewes in dependence on SCC class, Tvarožková et al., (2019), who analysed Tsigai, Lacaune and Slovak Dairy breed ewes, reported the following frequencies: about $88 \%$ in lowest class of SCC (under or equal to $200 \times 10^{3}$ cells.mL $\mathrm{mL}^{-1}$ ) and about $8 \%$ in highest class of SCC (above $1000 \times 10^{3}$ cells.mL ${ }^{-1}$ ) in 2017. Frequencies in 2018 were found to differ: about $21 \%$ and
$32 \%$ in lowest and highest class, respectively. High changes between years were probably due to fact that more heterogeneous data were studied (various breeds and various flocks) than data analysed in this study. These also might indicate differences in managment between 2017 and 2018. Idriss et al. (2015), reported highest proportion of ewes in lowest class of SCC and lowest proportion of ewes in highest class of SCC. These proportions slightly differed between breeds (Tsigai, Improved Valachian and Lacaune and their crossbreds, although the same pattern was was found in dependence of breed.

When comparing estimated changes in MY according to SCC class found in this study, these were between 12 and $25 \%$. Tančin et al., (2019), who also investigated relationships between MY and SCC in Lacaune breed, estimated these changes between 10 to $18 \%$. When investigated these changes on farm level (five farms), these changes were higher (Tančin et al., 2017). Sutera et al. (2018) reported that estimated losses in MY according to SCC level used were about $16 \%$ at maximum (in Valle del Belice ewes studied). Although no analyses of microrganisms in udders were done, the negative effect of increased SCC level on milk yield could be supposed when comparing with literature. For example, Martí De Olives et al. (2013), who performed the bacteriological analysis in Manchega ewes, found that milk yield between healthy and infected ewes differred by about $17 \%$ in favour of healthy ewes.

The fluctuation in LSM of MY (also of SCS) in dependence on year of measurement (Table 3) may indicate some problems in management practice of flock, especially when evaluating these traits between 2017 and 2018; probably worse conditions occurred in 2018. A rough increase of MY (and decrease of SCS) were found with increasing lactation number, although some differences were found non-significant (significant difference between first and second lactation was found). The effect of MIM showed significant influence on MY 
and SCS although variation of SCS was lower (less significant differences revealed) in comparison to variation of MY (more significant differences revealed). Finding about influence of lactation number partly agreed with previous studies (Oravcová et al., 2006; Oravcová, Mačuhová and Tančin, 2018), who reported no significant differences in MY in dependence on lactation number when LC, Tsigai (TS) and Improved Valachian (IV) ewes and LCxTS and LCxIV crosses were analysed. For $\log _{10}$ SCC, the latter authors revealed all differences between invidual lactations to be significant. Detailed comparisons of MY in this study and study of Oravcová, Mačuhová and Tančin (2018) those related LC ewes in the same flocks showed worse levels of flock mangement, also in terms of mastitis control might be supposed: in earlier period (2010-2013) higher MY was observed. ElSaied, Carriedo and San Primitivo (1998) reported that lactation number and stage of lactation (could be considered as MIM) significantly affected SCS in Churra ewes. In contrast, Othmane et al. (2002) found age of ewe (could be considered as lactation number) and stage of lactation to be non-significant when SCC in ewes of the same breed were analysed later. According to the latter authors, no differences were a result of strict mastitis control (teat dip after milking, selective dry therapy and culling of ewes with chronic mastitis) and high levels of husbandry applied in flocks investigated. The lower variation of SCS and higher variation of MY in dependence on stage of lactation was reported for French Lacaune ewes (Barillet et al., 2001).

The influence of interaction between MIM and SCC (Figure 1) was significant when MY (model 1) was analysed. Within individual months, some significant differences between SCC classes were revealed. However, most of differences were found between lower SCC classes (mostly MIM 2 and MIM 3) on the one hand and higher SCC classes (mostly MIM 4, MIM 5 and MIM 6) on the other hand. Comparisons with literature could not be done: to our best knowledge, no study which included interaction between MIM and SCC class in similar way was performed. However, a relationship between lactation stage and comatic cells showed that milk yield seemed to be of the higher influence on SCC at the end of lactation (MIM 6) than at the beginning, which is in accordance with findings of Arias et al. (2012).

Figure 1

When interation between MIM and MY class was considered when SCS (model 2) was analysed, the differences were non-significant, although trends were similar to those found when individual MIM and MY classes were investigated (not shown).

\section{CONCLUSION}

The findings of this study confirmed fact that somatic cells were present in ewe milk and may used to indicate udder health and contribue to improve levels of management, in terms of preventing the mastitis to be spread. Because number of somatic cells increases when infectious agents enter the udder, further research aimed at relationships between somatic cells, microorganisms and quality of ewe milk is needed.

\section{REFERENCES}

Arias, R., Oliete, B., Ramón, M., Arias, M. Gallego, R., Montoro, V., Gonzalo, C.Perez-Guzman, M.D. 2012. Longterm study of environmental effects on test-day somatic cell count and milk yield in Manchega sheep. Small Ruminant Research, vol. 106, no. 2-3, p. 92-97.

https://doi.org/10.1016/j.smallrumres.2012.03.019

Barillet, F., Rupp, R., Mignon-Grasteau, S., Astruc, J.-A., Jacquin, M. 2001. Genetic analysis for mastitis resistance and milk somatic cell score in French Lacaune dairy sheep. Genetics Selections Evolution, vol. 33, no. 4, p. 397-415. https://doi.org/10.1051/gse:2001124

Berthelot, X., Lagriffoul, G., Concordet, D., Barillet, F., Bergonier, D. 2006. Physiological and pathological thresholds of somatic cell counts in ewe milk. Small Ruminant Research, vol. 62 , no. $1-2$, p. 27-31.

https://doi.org/10.1016/j.smallrumres.2005.07.047

Burriel, A. R., 1997. Dynamics of intramammary infections in the sheep caused by coagulase-negative staphylococci and its influence on udder tissue and milk composition. The Veterinary Record, vol. 140, p. 419-423, https://doi.org/10.1136/vr.140.16.419

Caboni, P., Manis, C., Ibba, I., Contu, M., Coroneo, V., Scano, P. 2017. Compositional profile of ovine milk with a high somatic cell count: A metabolomics approach. International Dairy Journal, vol. 69, p. 33-39. https://doi.org/10.1016/j.idairyj.2017.02.001

El-Saied, U. M., Carriedo, J. A., San Primitivo, F. 1998.

Heritability of test day somatic cell counts and its relationship with milk yield and protein percentage in dairy ewes. Journal of Dairy Science, vol. 81, no. 11, p. 2956-2961.

https://doi.org/10.3168/jds.S0022-0302(98)75858-8

Gonzalo, C., Carriedo, J. A., Baro, J.A., San Primitivo, F. 1994. Factors influencing variation of test day milk yield, somatic cell count, fat and protein in dairy sheep. Journal of Dairy Science, vol. 77, no. 6, p. 1537-1542.

https://doi.org/10.3168/jds.S0022-0302(94)77094-6

Gonzáles-Rodríguez, M. C., Gonzalo, C., San Primitivo, F. C. 1995. Relationship between somatic cell count and intramammary infection of the half udder in dairy ewes. Journal of Dairy Science, vol. 78, no. 12, p. 2753-2759. https://doi.org/10.3168/jds.S0022-0302(95)76906-5

Idriss, Sh. E., Tančin, V., Margetín, M., Tančinová, D., Sláma, P., Havlíček, Z. 2015. The frequency of distribution of somatic cell count in dairy ewe's milk. Journal of Microbiology, Biotechechnolgy and Food Science, vol. 4 (special issue 3) p. 148-151

Hag, J. T. 2001. Somatic Cell Count Basics for Dairy Sheep. Avaiable

http://www.omafra.gov.on.ca/english/livestock/sheep/facts/sh eepmilkscc.html

Jaeggi, J., Govindasamy-Lucey, S. Berger, Y. M., Johnson, M. E., McKusick, B. C., Thomas, D. L., Wendorff, W. L. 2003. Hard Ewe's Milk Cheese Manufactured from Milk of Three Different Groups of Somatic Cell Counts. Journal of Dairy Science, vol. 86, no. 10, p. 3082-3089. https://doi.org.10.3168/jds.S0022-0302(03)73908-3

Kern, G., Traulsen, I., Kemper, N., Krieter, J. 2013. Analysis of somatic cell counts and risk factors associated with occurrence of bacteria in ewes of different primary purposes. Livestock Science, vol. 157, no. 2-3, p. 597-604. https://doi.org/10.1016/j.livsci.2013.09.008

Martí De Olives, A. Díaz, J. R., Molina, M. P., Peris, C. 2013. Quantification of milk yield and composition changes as affected by subclinical mastitis during the current lactation 
in sheep. Journal of Dairy Science, vol. 96, no. 12, p. 30823089. https://dx.doi.org.10.3168/jds.201-6998

Oravcová, M., Margetín, M., Peškovičová, D., Daňo, J., Milerski, M., Hetényi, L., Polák, P. 2006. Factors affecting milk yield and ewe's lactation curves estimated with test-day models. Czech J. Anim. Sci., vol. 51, no. 11, p. 483-490. https://doi.org/10.17221/3968-CJAS

Oravcová, M., Mačuhová, L., Tančin, V. 2018. The relationship between somatic cells and milk traits, and their variation in dairy sheep breeds in Slovakia. Journal of Animal and Feed Sciences, vol. 27, no. 2, p. 97-104. https://doi.org/10.22358/jafs/90015/2018

Othmane, M. H., Carriedo, J. A., De La Fuente, L. F., San Primitivo, F. 2002. Factors affecting test-day milk composition in dairy ewes, and relationships amongst various milk components. Journal of Dairy Research, vol. 69, no. 1, p. 53-62. https://doi.org.10.1017/s.0022029901005234

Pengov, A. 2001. The role of coagulase-negative Stahylococcus spp. and associated somatic cell count in the ovine mammary gland. Journal of Dairy Science, vol. 84, p. 572-574. https://doi.org/10.3168/jds.s0022-0302(01)74509-2 Riggio, V., Finocchiaro, R., van Kaam, J. B., Portolano, B., Bovenhuis, H. 2007. Genetic parameters for milk somatic cell score and relationships with production traits in primiparous dairy sheep. Journal of Dairy Science, vol. 90, no. 4, p. 19982003. https://doi.org/10.3168/jds.2006-309

SAS Institute Inc. 2009. SAS/STAT ${ }^{\circledR} 9.2$ User's Guide, Second Edition, Cary, NC USA

Sutera, A. M., Portolano, B., Di Gerlando, R., Sardina, M. T., Mastrangelo, S., Tolone, M. 2018. Determination of milk production losses and variations of fat and protein percentages according to different levels of somatic cell count in Valle del Belice dairy sheep. Small Ruminant Research, vol. 162, p. 39-42. https://doi.org/10.1016/j.smallrumres.2018.03.002

Tančin, V., Uhrinčat', M., Mačuhová, L., Baranovič, Š., Vršková, M. 2017. Somatic cell count in milk of individual Lacaune ewes under practical conditions in Slovakia: Possible effect on milk yield and its composition. Potravinarstvo Slovak Journal of Food Sciences, vol. 11, no. 1, p. 386-390. https://doi.org/10.5219/767

Tančin, V., Tvarožková, K., Mačuhová, L., Uhrinčat', M., Vršková, M. 2019. Somatic cell count in milk of ewes and possible effect on milk yield and composition. ICPD 2019. Bern: University of Bern, 2019, p. 217. ISBN 978-3-90681393-6.
Tvarožková, K., Tančin, V., Uhrinčat', M., Mačuhová, L., Vršková, M., Oravcová, M. 2019. Somatic cell count first and second lactation in ewes. Potravinarstvo Slovak Journal of Food Sciences, vol. 13, no. 1, p. 396-401. https://doi.org/10.5219/1059

\section{Acknowledgments:}

This article was possible through the Project No. APVV-150072, which was supported by the Ministry of Education, Science, Research and Sports of the Slovak Republic. Thanks are due to Plemenárske služby š.p. Bratislava for data availability.

\section{Contact address:}

*Marta Oravcová, NAFC-Research Institute for Animal Production Nitra, Hlohovecká 2, 95141 Lužianky, Slovakia, +421376546378 ,

E-mail: marta.oravcova@nppc.sk

ORCID: https://orcid.org/0000-0002-7823-8911

Kristína Tvarožková, Slovak University of Agriculture, Faculty of Agrobiology and Food Resources, Department of Veterinary Science, Tr. A. Hlinku 2, 94976 Nitra, Slovakia, Tel.: +421944385272,

E-mail: kristina.tvarozkova@gmail.com

ORCID: https://orcid.org/0000-0003-4989-6138

Vladimír Tančin, Slovak University of Agriculture, Faculty of Agrobiology and Food Resources, Department of veterinary science, Tr. A. Hlinku 2, 94976 Nitra Slovakia; NAFC-Research Institute for Animal Production Nitra, Hlohovecká 2, 95141 Lužianky Slovakia, Tel.: +421903546401,

E-mail: vladimir.tancin@nppc.sk

ORCID: https://orcid.org/0000-0003-2908-9937

Michal Uhrinčat', NAFC-Research Institute for Animal Production Nitra, Hlohovecká 2, 95141 Lužianky, Slovakia, Tel.: +421376546656,

E-mail: michal.uhrincat@nppc.sk

ORCID: https://orcid.org/0000-0002-5378-617X

Lucia Mačuhová, NAFC-Research Institute for Animal Production Nitra, Hlohovecká 2, 95141 Lužianky, Slovakia, Tel.: +4213765466571,

E-mail: lucia.macuhova@nppc.sk

ORCID: https://orcid.org/0000-0002-9624-1348

Corresponding author: * 